\title{
Epidemiology and Characteristics of Burn Patients in Dr. Soedarso General Hospital during 2017 - 2020: Retrospective Study
}

\author{
Doni Setiawan ${ }^{1}$, Winsen Haryono ${ }^{2 * \mathbb{D}}$ \\ ${ }^{1}$ Department of Surgery, Division of Plastic, Aesthetic and Reconstructive Surgery, Dr. Soedarso General Hospital, Pontianak, \\ Indonesia; ${ }^{2}$ General Practitioner, Dr. Soedarso General Hospital, Pontianak, Indonesia
}



\section{Introduction}

Burns are a complex problem and often occur in everyday life, especially in low and middle-income countries [1], [2]. Burns are caused by various etiology, namely fire, hot water, electricity, chemistry, contact, radiation, and cold trauma [2]. According to the World Health Organization, around 180,000 people worldwide die from burns [2]. The United States in 2008 had 410,000 burn cases. Where it occurs most in men than women [2]. The incidence of burns in adults is most often caused by fire, while in children it is caused by hot water [1], [3]. In addition to affecting the patient from a physical aspect, burns can also be psychosocial and functional patients, thus affecting the quality of life of the patient [4], [5]. Management of burns must also improve the quality of life of the patient [4].

Based on research data from Cipto Mangunkusumo Hospital (RSCM) in 2011 to 2012 found 303 burn patients, most cases were found in men compared to women with a ratio of $2.26: 1$, with an average age of 25.7 years of patients (15-54 years), the area of burns is $20-50 \%$ in about $45.87 \%$ of cases [3]. In adults, the most etiologic cases of burns in RSCM in 2012-2016 were 53.1\%; hot water $19.1 \%$; electricity
$14 \%$; $5 \%$ contact; and chemistry $3 \%$, while children mostly caused by hot water $52 \%$, fire $26 \%$, contact $15 \%$, electricity $6 \%$, and chemistry $1 \%$ [3].

The purpose of this study was to determine the epidemiological data and characteristics of burn patients at Dr. Soedarso General Hospital. The results of this study are expected to be additional data on the epidemiology of burns in Indonesia.

\section{Methods}

The research design used a retrospective study. The sampling method was non-random consecutive sampling. The population of this study were all burn patients at Dr. Soedarso General Hospital in the period August 2017-December 2020. Medical record data is in the form of patient demographic data in the form of gender, age, etiology of burn, burn depth, and total burn area/total body surface area (TBSA), and mortality data. Age was divided into children ( $\leq 18$ years) and adults (>18 years). Data analysis using the IBM SPSS Statistics 23 application. 


\section{Results}

The number of burn cases in Dr. Soedarso General Hospital in the period August 2017-December 2020, there were 108 respondents. Where the most cases were found in 2019 , total of $50(46.3 \%)$ respondents, in 2020 there was a decrease in cases, there were $20(18.5 \%)$ respondents (Figure 1$)$.

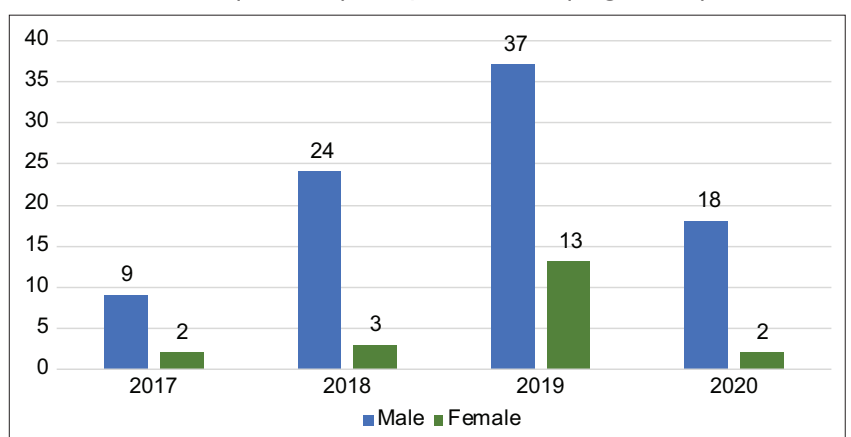

Figure 1: Burn patients during 2017-2020

The most cases of burns occurred in males $88(81.5 \%)$ and $20(18.5 \%)$ females, with a male-tofemale ratio of $4.4: 1$. Patients were children ( $\leq 18$ years), total of $51(47.2 \%)$ respondents and adults ( $>18$ years) $57(52.8 \%)$ respondents (Table 1$)$.

Table 1: Distribution of sex and age

\begin{tabular}{llll}
\hline Sex & $\leq 18$ years $\mathrm{n}(\%)$ & $>18$ years $\mathrm{n}(\%)$ & Total $\mathrm{n}(\%)$ \\
\hline Male & $37(34.2)$ & $51(47.2)$ & $88(81.5)$ \\
Female & $14(13)$ & $6(5.6)$ & $20(18.5)$ \\
Total & $51(47.2)$ & $57(52.8)$ & $108(100)$ \\
\hline
\end{tabular}

Judging from the etiology of burns, the most cases were caused by fire, total $38(35.2 \%)$ respondents. The most cases of burns in male with etiology were caused by electricity, $37(34.3 \%)$ cases, while in female were caused by scald $12(11.1 \%)$. In addition, adults (>18 years) were most affected by burns, total of $57(52.8 \%)$ respondents with the most etiology of electricity $29(26.9 \%)$ respondents (Table 2).

Table 2: Distribution of burns etiology by sex and age

\begin{tabular}{llllll}
\hline Parameter Etiology & Male $\mathrm{n}(\%)$ & $\begin{array}{l}\text { Perempuan } \\
\mathrm{n}(\%)\end{array}$ & $\begin{array}{l}\mathbf{s} \mathrm{i} \text { years } \\
\mathrm{n}(\%)\end{array}$ & $\begin{array}{l}>18 \text { years } \\
\mathrm{n}(\%)\end{array}$ & Total $\mathrm{n}(\%)$ \\
\hline Flame & $30(27.8)$ & $8(7.4)$ & $20(18.5)$ & $18(16.7)$ & $38(35.2)$ \\
Electric & $37(34.3)$ & $0(0)$ & $8(7.4)$ & $29(26.9)$ & $37(34.3)$ \\
Scald & $21(19.4)$ & $12(11.1)$ & $23(21.3)$ & $10(9.3)$ & $33(30.6)$ \\
Chemical & $0(0)$ & $0(0)$ & $0(0)$ & $0(0)$ & $0(0)$ \\
Contact & $0(0)$ & $0(0)$ & $0(0)$ & $0(0)$ & $0(0)$ \\
Total & $88(81.5)$ & $20(18.5)$ & $51(47.2)$ & $57(52.8)$ & $108(100)$ \\
\hline
\end{tabular}

Judging from the depth of burns, the most cases were $2^{\text {nd }}{ }^{\circ}$ - burns with a total of $77(71.3 \%)$ respondents. Adults (>18 years) experienced more cases of burns, $57(52.8 \%)$ respondents with IIAB degree burns $36(33.3 \%)$ respondents (Table 3$)$.

Table 3: Distribution of depth of burns for sex and age

\begin{tabular}{llllll}
\hline Parameter Depth of Burns & $\begin{array}{l}\text { Male } \mathrm{n} \\
(\%)\end{array}$ & $\begin{array}{l}\text { Female } \\
\mathrm{n}(\%)\end{array}$ & $\begin{array}{l}\leq 18 \text { years } \\
\mathrm{n}(\%)\end{array}$ & $\begin{array}{l}>18 \text { years } \\
\mathrm{n}(\%)\end{array}$ & $\begin{array}{l}\text { Total } \mathrm{n} \\
(\%)\end{array}$ \\
\hline IIAB & $58(53.7)$ & $19(17.6)$ & $41(38)$ & $36(33.3)$ & $77(71.3)$ \\
III & $30(27.8$ & $1(0.9)$ & $10(9.3)$ & $21(19.4)$ & $31(28.7)$ \\
Total & $88(81.5)$ & $20(18.5)$ & $51(47.2)$ & $57(52.8)$ & $108(100)$ \\
\hline
\end{tabular}

The TBSA was $1-10 \%$ in $43(39.8 \%)$ respondents. Most of them occurred in male gender, total of $88(81.5 \%)$ respondents and in adult ( $>18$ years) $57(52.8 \%)$ respondents (Table 4$)$.

Table 4: Distribution of TBSA by sex and age

\begin{tabular}{llllll}
\hline Parameter TBSA (\%) & $\begin{array}{l}\text { Male } \mathrm{n} \\
(\%)\end{array}$ & $\begin{array}{l}\text { Female } \\
\mathrm{n}(\%)\end{array}$ & $\begin{array}{l}\leq 18 \text { years } \\
\mathrm{n}(\%)\end{array}$ & $\begin{array}{l}>18 \text { years } \\
\mathrm{n}(\%)\end{array}$ & Total $\mathrm{n}(\%)$ \\
\hline $1-10$ & $35(32.4)$ & $8(7.4)$ & $21(19.4)$ & $22(20.4)$ & $43(39.8)$ \\
$11-20$ & $24(22.2)$ & $4(3.7)$ & $9(8.3)$ & $19(17.6)$ & $28(25.9)$ \\
$21-30$ & $14(13.7)$ & $5(4.6)$ & $13(12)$ & $6(5.6)$ & $19(17.6)$ \\
$31-40$ & $7(6.5)$ & $1(0.9)$ & $3(2.8)$ & $5(4.6)$ & $8(7.4)$ \\
$41-50$ & $3(2.8)$ & $0(0)$ & $3(2.8)$ & $0(0)$ & $3(2.8)$ \\
$51-60$ & $4(3.7)$ & $0(0)$ & $1(0.9)$ & $3(2.8)$ & $4(3.7)$ \\
$61-70$ & $0(0)$ & $1(0.9)$ & $1(0.9)$ & $0(0)$ & $1(0.9)$ \\
$71-100$ & $1(0.9)$ & $1(0.9)$ & $0(0)$ & $2(1.9)$ & $2(1.9)$ \\
Total & $88(81.5)$ & $20(18.5)$ & $51(47.2)$ & $57(52.8)$ & $108(100)$ \\
\hline
\end{tabular}

The hospital length of stay we found that median was 10.00 (1.00-96.00) days. The length of stay mean was 16.15 days. The study found that $57(52.8 \%)$ patients were treated for 1-10 days (Table 5).

Table 5: Distribution of hospital length of stay on burn patients

\begin{tabular}{llll}
\hline Parameter & Day $\mathrm{n}(\%)$ & Mean \pm SD & Median (Min; Max) \\
\hline Length of stay & & $16.15 \pm 17.145$ & $10.00(1 ; 96)$ \\
$1-10$ & $57(52.8)$ & & \\
$11-20$ & $24(22.2)$ & & \\
$21-30$ & $11(10.2)$ & & \\
$31-40$ & $9(8.3)$ & & \\
$41-100$ & $7(6.5)$ & & \\
Total & $108(100)$ & & \\
\hline
\end{tabular}

Cases of mortality rate in male were $6(5.6 \%)$ respondents and $2(1.9 \%)$ women respondents. Then, in children ( $\leq 18$ years) cases, total of $3(2.8 \%)$ respondents and adults (>18 years) $5(4.6 \%)$ respondents. The etiology of the cause of death was mostly caused by flame for $3(2.8 \%)$ respondents and scald for $3(2.8 \%)$ respondents (Table 6).

Table 6: Distribution based on life and death rates

\begin{tabular}{llll}
\hline Parameter & Lived cases $\mathrm{n}(\%)$ & Died cases $\mathrm{n}(\%)$ & Total $\mathrm{n}(\%)$ \\
\hline $\begin{array}{l}\text { Gender } \\
\text { Male }\end{array}$ & $82(75.9)$ & $6(5.6)$ & $88(81.5)$ \\
$\quad$ Female & $18(16.7)$ & $2(1.9)$ & $20(18.5)$ \\
Age & & & \\
S18 years & $48(44.4)$ & $3(2.8)$ & $51(47.2)$ \\
$>18$ years & $52(48.1)$ & $5(4.6)$ & $57(52.8)$ \\
Etiology & & & \\
Flame & $35(32.4)$ & $3(2.8)$ & $37(35.2)$ \\
Electric & $35(32.4)$ & $2(1.9)$ & $36(34.2)$ \\
Scald & $30(27.8)$ & $3(2.8)$ & $33(30.6)$ \\
Chemical & $0(0)$ & $0(0)$ & $0(0)$ \\
Contact & $0(0)$ & $0(0)$ & $0(0)$ \\
TBSA $(\%)$ & & $0(0)$ & $43(39.8)$ \\
$1-10$ & $43(39.8)$ & $0(0)$ & $28(25.9)$ \\
$11-20$ & $28(25.9)$ & $0(0)$ & $19(17.6)$ \\
$21-30$ & $19(17.6)$ & $2(1.9)$ & $8(7.4)$ \\
$31-40$ & $6(5.6)$ & $1(0.9)$ & $3(2.8)$ \\
$41-50$ & $2(1.9)$ & $2(1.9)$ & $4(3.7)$ \\
$51-60$ & $2(1.9)$ & $1(0.9)$ & $1(0.9)$ \\
$61-70$ & $0(0)$ & $2(1.9)$ & $108(10)$ \\
$71-100$ & $0(0)$ & $8(7.4)$ & \\
Total & $100(92.6)$ & & \\
\hline
\end{tabular}

\section{Discussion}

This study is an epidemiological study and the characteristics of burns at Dr. Soedarso General Hospital. The data in this study came from patient medical records; This hospital is a health service provider in the tiered referral system in Indonesia. Burn cases were also referred to this hospital. All burn cases were examined and managed by a plastic surgeon.

This research study found the total cases of burns in Dr. Soedarso General Hospital, namely 108 
respondents in the 2017-2020 period. Research conducted by Wardhana et al. at Cipto Mangunkusumo Hospital in Burns Unit in 2013-2015 found 414 respondents [6]. In 2020, the COVID-19 pandemic resulted in a decrease in burn cases. This also happened in the UK in a study conducted by Azzam Farroha which had a 33\% reduction in cases [7].

Burns were more common in males than females with a ratio of $4.4: 1$. These results are consistent with research conducted by Frans et al. [8], Wardhana et al. [6], and Pande et al. [9]. Males are more often exposed to burns due to the surrounding environment and work risks [6]. From our observations, it was found that the most frequent burn cases were in adults (>18 years), total $57(52.8 \%)$ respondents. This study was supported by Zheng et al. it also found that more burn cases occurred in adults (52.5\%) [10]. In this study, flame $(35.2 \%)$ and electric $(34.3 \%)$ were found to be the most common causes. The results of KC Pande's research which found that the etiology of burns was mostly caused by scald $(78.2 \%)$ due to boiling water, especially when it occurred at home [9]. Research on electrical burns conducted by D. Kym in South Korea In 2005-2011, 625 patients were found, most of whom were workmen or electricians, it was said that electric burns resulted in a high rate of morbidity and mortality as well as serious tissue damage [11]. The mortality rate obtained was $0-21.7 \%$ [11]. Most of the $2^{\text {nd }}-{ }^{\circ}$ burns (68.9\%). This result is in accordance with the research conducted by Fiera Avrillia Ferdianty and Santi Devina, namely, $2^{\text {nd }}{ }^{\circ}$ burns of $81.3 \%$, mostly in adults $50.7 \%$ [12].

Children ( $\leq 18$ years) were most often exposed to scald (21.3\%). Research conducted by Grivna et al. [13], Palmieri et al. [14] and Frans et al. [8] stated that hot water, hot soup, and hot oil are the most common causes of burns in the house.

The median length of stay in the previous study by Wardhana et al. [6] was 11.00 days, Yao et al. [15] study found 11.00 days. The study conducted by Louise et al. [16] found several causes that caused patients to be treated for a long time in the hospital, namely burn depth, burn location, infection or sepsis, and the need for surgical intervention or dressing change.

The mortality rate found in this study was $7.4 \%$, in a previous study conducted by Nungki Ratna Martina and Aditya Wardhana it was $26.7 \%$ [17]. The cause of death in burn cases was caused by septicemia (42.1\%), multiple failures. organs (31.6\%), SIRS (Systemic Inflammatory Response Syndrome) (17.6\%), and acute respiratory failure $(8.7 \%)$ [17].

In this study, additional data were limited, such as the socio-economic status of the patient, the comorbid illnesses suffered, and the location of the burns that were incomplete, thus limiting the analysis of patient characteristics data. For future researchers, it is advisable to look for patient mortality rates, cure rates, complications, and prognosis of burn patients.

\section{Conclusion}

This study describes the epidemiology and characteristics of burn patients at Dr. Soedarso General Hospital in the period August 2017 to December 2020, cases of burns in children ( $\leq 18$ years) were more often caused by scald, while in adults ( $>18$ years) by electric and flame.

\section{References}

1. Rybarczyk MM, Schafer JM, Elm CM, Sarvepelli S, Vaswani PA A systematic review of burn injuries in low- and middle-income countries: Epidemiology in the WHO-defined African Region. Afr J Emerg Med. 2017;7(1):30-7. https://doi.org/10.1016/j. afjem.2017.01.006

PMid:30456103

2. World Health Organization. Burns; 2018. Available from: https://www.who.int/news-room/fact-sheets/detail/burns. [Last accessed on 2021 Jan 27].

3. Indonesian Ministry of Health. National Guidelines for Medical Services for Burn Wound Management. Jakarta, Indonesia: Indonesian Ministry of Health; 2019.

4. Khan MS, Rehan M, Ali U, Iqbal T. Epidemiology of burns: A decade experience. JSM Burns Trauma. 2018;3(2):1042.

5. Elsherbiny OE, Salem MA, Sabbagh AH, Elhadidy MR, Eldeen SM. Quality of life of adult patients with severe burns. Burns. 2011;37(5):776-89. https://doi.org/10.1016/j. burns.2010.12.017

PMid:21466924

6. Wardhana A, Basuki A, Prameswara AD, Rizkita DN, Andarie AA Canintika AF. The epidemiology of burns in Indonesia's national referral burn Center from 2013 to 2015. Burns Open. 2017;1(2):67-73. https://doi.org/10.1016/j.burnso.2017.08.002

7. Farroha A. Effects of COVID-19 pandemic on burns epidemiology. Burns. 2020;46(6):1466. https://doi.org/10.1016/j. burns.2020.05.022 PMid:32507521

8. Frans FA, Keli SO, Maduro AE. The epidemiology of burns in a medical center in the Caribbean. Burns. 2008;34(8):1142-8. https://doi.org/10.1016/j.burns.2008.05.013

PMid:18786771

9. Pande $\mathrm{KC}$, Ishak $\mathrm{HL}$. Epidemiology of burns in a major referral hospital in Brunei Darussalam. Singapore Med J. 2012;53(2):124-7.

PMid:22337188

10. Zheng $\mathrm{Y}$, Lin G, Zhan R, Qian W, Yan T, Sun L, et al Epidemiological analysis of 9,779 burn patients in China: An eight-year retrospective study at a major burn Center in Southwest China. Exp Ther Med. 2019;17(4):2847-54. https:// doi.org/10.3892/etm.2019.7240

PMid:30930977

11. Kym D, Seo DK, Hur GY, Lee JW. Epidemiology of electrical injury: Differences between low- and highvoltage electrical injuries during a 7-year study period in South Korea. Scand J Surg. 2015;104(2):108-14. https://doi. org/10.1177/1457496914534209

PMid:24809357

12. Ferdianty FA, Devina S. Epidemiology of burns injury in 
Dr. Iskak general hospital Tulungagung: Two years (2017-2018) retrospective study. J Plastik Rekonstruksi. 2020;7(1):28-34. https://doi.org/10.14228/jpr.v7i1.280

13. Grivna M, Eid HO, Zidan FM. Epidemiology of burns in the United Arab Emirates: Lessons for prevention. Burns. 2014;40(3):500-5. https://doi.org/10.1016/j.burns.2013.08.010 PMid:24011735

14. Palmieri TL, Alderson TS, Ison D, O'Mara MS, Sharma R, Bubba $A$, et al. Pediatric soup scald burn injury: Etiology and prevention. J Burn Care Res. 2008;29(1):114-8. https://doi. org/10.1097/bcr.0b013e31816017d7

15. Yao Y, Liu Y, Zhou J, et al. The epidemiology of civilian inpatients' burns in Chinese military hospitals, 2001-2007. Burns. 2011;37(6):1023-32. burns.2011.03.021

PMid:21546162

16. Louise $\mathrm{CN}$, David M, John SK. Is the target of 1 day length of stay per $1 \%$ total body surface area burned actually being achieved? A review of paediatric thermal injuries in South East Scotland. Int J Burns Trauma. 2014;4(1):25-30.

PMid:24624311

17. Martina NR, Wardhana A. Mortality analysis of adult burn patients. J Plastik Rekonstruksi. 2013;2(2):96-100. https://doi. org/10.14228/jpr.v2i2.155 